\title{
Kinetics and Mechanism of Allene Racemization Catalyzed by a Gold $N$ - Heterocyclic Carbene Complex
}

\author{
Hao Li, Robert J. Harris, Kohki Nakafuku, and Ross A. Widenhoefer* \\ Duke University, Department of Chemistry, French Family Science Center, Durham, NC, 27708
}

Supporting information

Experimental procedures, spectroscopic and analytical data for new compounds, and NMR spectra for allenes (14 pages). 


\section{Experimental}

General Methods. Reactions were performed under a nitrogen atmosphere employing standard Schlenk and drybox techniques unless specified otherwise. NMR spectra were obtained on Varian spectrometers operating at $400 \mathrm{MHz}$ for ${ }^{1} \mathrm{H}$ NMR and $101 \mathrm{MHz}$ for ${ }^{13} \mathrm{C} \mathrm{NMR}$ in $\mathrm{CDCl}_{3}$ at $25^{\circ} \mathrm{C}$ unless noted otherwise. HPLC traces were obtained using a Shimadzu LC-2010A HT Liquid Chromatograph equipped with either a $0.46 \mathrm{~cm} \times 25 \mathrm{~cm}$ Chiralpak AD-H column or a $0.46 \mathrm{~cm} \times 25$ $\mathrm{cm}$ Phenomenex Lux $5 \mu$ Cellulose-1 column and a UV detector operating a $210 \mathrm{~nm}$ using a hexanes-isopropanol eluent system. Gas chromatography for determination of enantiomeric ratios was performed on a Hewlett-Packard 5890 gas chromatography equipped with a $20 \mathrm{~m} \times 0.25 \mathrm{~mm}$ Chiraldex G-TA column. Column chromatography was performed employing 230-400 mesh silica gel (Silicycle). Catalytic reactions were performed in sealed glass tubes under an atmosphere of dry nitrogen unless noted otherwise. Elemental analyses were performed by Complete Analysis Laboratories (Parsippany, NJ). Thin layer chromatography (TLC) was performed on silica gel $60 \mathrm{~F}_{254}$ (EMD Chemicals Inc.). Room temperature is $23^{\circ} \mathrm{C}$.

All solvents were purchased from Aldrich or Acros in anhydrous form and used as received. All reagents were purchased from major suppliers and used as received. Metal complexes (P1)AuCl, (IPr)AuCl, and AgOTf were used as received. (R)-4-(4-(Trifluoromethyl)phenyl)-3-butyn-2-ol (S1), ${ }^{\mathrm{S} 1}$ $(R)-4-p$-tolylbut-3-yn-2-ol (S2), ${ }^{\mathrm{S} 2}(R)$-1-phenyl-1,2-butadiene $\left[(R)-3 \mathbf{a} ; 78 \%\right.$ ee], ${ }^{\mathrm{S} 3}(S)-2,3-$ pentadienyl benzoate $\left[(S)-1,97 \%\right.$ ee], ${ }^{S 3}$ and $(R)-1$-(buta-1,2-dienyl)-4-nitrobenzene $[(R)-3 \mathbf{d} ; 91 \%$ ee $],{ }^{S 4}$ were prepared and analyzed employing published procedures.

\section{Synthesis of enantiomerically enriched aryl allenes}

$(R)-1-(1,2-B u t a d i e n y l)-4-(t r i f l u o r o m e t h y l) b e n z e n e \quad[(R)-3 c]$. Diethylazodicaboxylate (1.4 $\mathrm{mL}, 8.8 \mathrm{mmol})$ was added to a solution of triphenylphosphine $(2.3 \mathrm{~g}, 8.8 \mathrm{mmol})$ in THF $(15 \mathrm{~mL})$ at $10{ }^{\circ} \mathrm{C}$ over $1 \mathrm{~min}$. The resulting solution was stirred at $-10{ }^{\circ} \mathrm{C}$ for $10 \mathrm{~min}$, treated with a solution of 
S1 $(1.45 \mathrm{~g}, 6.8 \mathrm{mmol} ; \geq 95 \% \mathrm{ee})$ in THF $(10 \mathrm{~mL})$, stirred for $10 \mathrm{~min}$, and treated with a solution of $o_{-}$ nitrobenzenesulfonyl hydrazine $(1.9 \mathrm{~g}, 8.8 \mathrm{mmol})$ in THF $(15 \mathrm{~mL}) .{ }^{\mathrm{S} 5}$ The resulting mixture was stirred between $-10{ }^{\circ} \mathrm{C}$ and $0{ }^{\circ} \mathrm{C}$ for $2 \mathrm{~h}$, warmed to room temperature, and stirred overnight. The reaction mixture was cooled to $0{ }^{\circ} \mathrm{C}$, diluted with $\mathrm{Et}_{2} \mathrm{O}$, washed with ice water, dried $\left(\mathrm{MgSO}_{4}\right)$, and concentrated. The resulting residue was chromatographed (hexane) to give $(R)-3 \mathrm{c}(1.0 \mathrm{~g}, 74 \%)$ as a colorless oil. TLC (hexane): $R_{f}=0.69 .{ }^{1} \mathrm{H}$ NMR: $\delta 7.54(\mathrm{~d}, J=8.0 \mathrm{~Hz}, 2 \mathrm{H}), 7.38(\mathrm{~d}, J=8.0 \mathrm{~Hz}, 2$ $\mathrm{H}), 6.14-6.10(\mathrm{~m}, 1 \mathrm{H}), 5.61$ (quintet, $J=7.0 \mathrm{~Hz}, 1 \mathrm{H}$ ), 1.81 (ddd, $J=1.2,3.2,7.2 \mathrm{~Hz}, 3 \mathrm{H}$ ). ${ }^{13} \mathrm{C}\left\{{ }^{1} \mathrm{H}\right\}$ NMR: $\delta 207.1,139.3,128.8\left(q,{ }^{2} J_{C F}=32.4 \mathrm{~Hz}\right), 126.9,125.7\left(q,{ }^{3} J_{C-F}=4.0 \mathrm{~Hz}\right), 124.5\left(q,{ }^{1} J_{C F}=\right.$ 271.9 Hz), 93.2, 90.2, 13.8. IR (neat, $\mathrm{cm}^{-1}$ ): 2930, 1615, 1322, 1162, 1119, 1064, 1016, 875, 843, 754. HRMS calcd (found) for $\mathrm{C}_{11} \mathrm{H}_{9} \mathrm{~F}_{3}\left(\mathrm{M}^{+}\right)$: 198.0656 (198.0657). The enantiopurity of $(R)-3 \mathrm{c}(95 \%$ ee) was determined by GC analysis employing chiral stationary phase $\left[t_{r}\right.$ (major) $=101.0 \mathrm{~min}, t_{r}$ $($ minor $\left.)=98.9 \min \left(15 \mathrm{psi}, 45^{\circ} \mathrm{C}\right)\right]$.

$(R)$-1-(Buta-1,2-dienyl)-4-methylbenzene $[(R)-3 b] .{ }^{\text {S6 }} \quad$ Allene $(R)-3 b$ was synthesized from S2 $(0.28 \mathrm{~g}, 1.1 \mathrm{mmol}, \geq 97 \% \mathrm{ee})$ employing a procedure analogous to that used to synthesize $(R)-3 \mathrm{c}$. Colorless oil, 53\%. ${ }^{1} \mathrm{H}$ NMR: $\delta 7.27(\mathrm{~d}, J=8.0 \mathrm{~Hz}, 2 \mathrm{H}), 7.18(\mathrm{~d}, J=8.0 \mathrm{~Hz}, 2 \mathrm{H}), 6.18-6.14(\mathrm{~m}, 1 \mathrm{H})$, 5.59 (quintet, $J=6.8 \mathrm{~Hz}, 1 \mathrm{H}$ ), $2.40(\mathrm{~s}, 3 \mathrm{H}), 1.81$ (dd, $J=3.2,7.2 \mathrm{~Hz}, 3 \mathrm{H}$ ). ${ }^{13} \mathrm{C}\left\{{ }^{1} \mathrm{H}\right\} \mathrm{NMR}: \delta \quad 205.7$, $136.3,132.0,129.2,126.5,93.8,89.4,29.7,21.1,14.1$. The enantiopurity of $(R)-3 b$ (97 \% ee) was determined by HPLC analysis employing chiral stationary phase $\left[\mathrm{t}_{\mathrm{r}}\right.$ (major) $=40.3 \mathrm{~min}, \mathrm{t}_{\mathrm{r}}($ minor $)=$ $38.5 \mathrm{~min}$ (hexanes-isopropanol=99.9:0.1@ 0.5 mL/min)]. 


\section{Kinetic Experiments}

Figure S1. Pseudo first-order plots for the racemization of $(S)-1(100 \mathrm{mM})$ catalyzed by a $1: 2$ mixture of (IPr)AuCl (10 mM) and $\operatorname{AgOTf}(20 \mathrm{mM} ; \square)$ and by a 2:1 mixture of (IPr)AuCl (10 mM) and $\operatorname{AgOTf}(5 \mathrm{mM} ; \mathrm{O})$ in toluene at $25^{\circ} \mathrm{C}$.

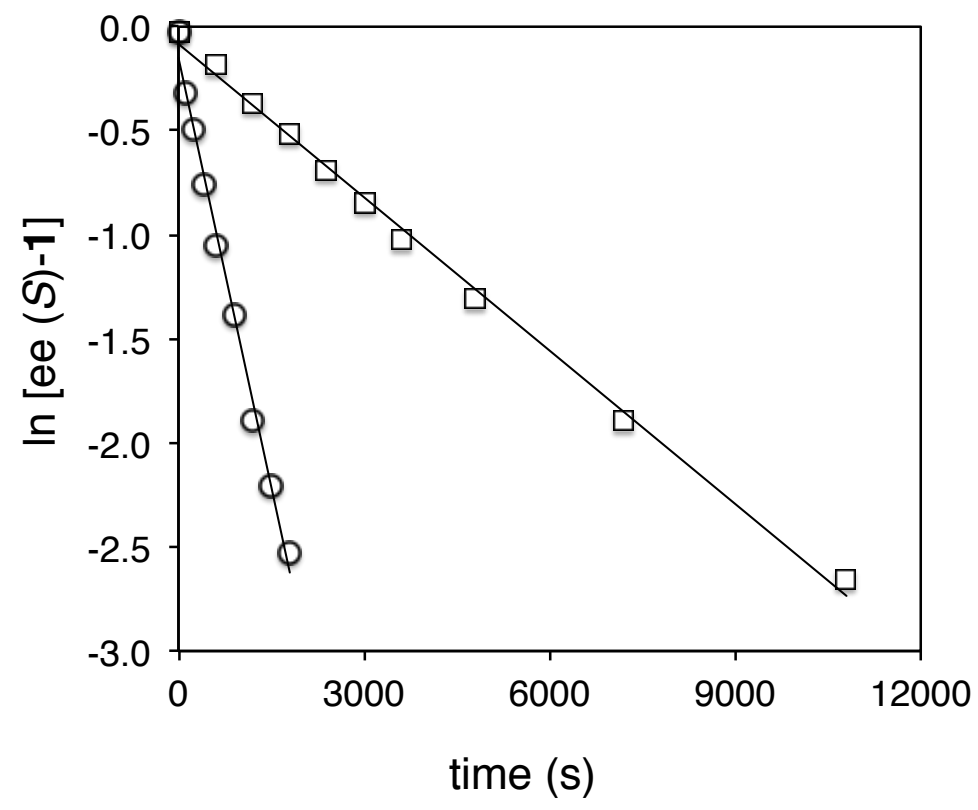

Kinetic Analysis of the Racemization of 1-Aryl-1,2-butadienes. A solution of (IPr)AuOTf $\left(5.0 \times 10^{-3} \mathrm{mmol}\right)$ in toluene was prepared by stirring (IPr)AuCl $\left(3.1 \mathrm{mg}, 5.0 \times 10^{-3} \mathrm{mmol}\right)$ and AgOTf $\left(1.3 \mathrm{mg}, 5.0 \times 10^{-3} \mathrm{mmol}\right)$ in toluene $(15 \mathrm{~mL})$ for $5 \mathrm{~min}$ at $25^{\circ} \mathrm{C}$. To this was added a solution of $(R)$ 3a $(65 \mathrm{mg}, 0.5 \mathrm{mmol})$ in toluene $(10 \mathrm{~mL})$ total volume $=25 \mathrm{~mL},[(R)-3 \mathrm{a}]=20 \mathrm{mM},[(\operatorname{IPr})$ AuOTf $]=$ $0.20 \mathrm{mM}\}$ and the resulting solution was stirred in a thermostatted oil bath at $25 \pm 0.5^{\circ} \mathrm{C}$. To monitor reaction progress, aliquots were removed periodically via syringe and analyzed by GC employing chiral stationary phase $\left[t_{r}(\right.$ major $)=31.8 \mathrm{~min}, t_{r}($ minor $)=29.0 \mathrm{~min} ; 15 \mathrm{psi}, 50{ }^{\circ} \mathrm{C}$ ]. A plot of In [ee (R)-3a] versus time was linear to $\sim 3$ half-lives with a pseudo first-order rate constant of $k_{\mathrm{obs}}=5.17 \pm$ $0.05 \times 10^{-4} \mathrm{~s}^{-1}$ (Figure S2, Table 1, entry 8). Pseudo first-order rate constants for the racemization of (R)-3a catalyzed by (IPr)AuOTf were determine as a function of temperature at 9,41 , and $50{ }^{\circ} \mathrm{C}$ employing analogous procedures (Figure S3, Table 1, entries 11-13). Activation parameters for the 
racemization of $(R)$-3a catalyzed by (IPr)AuOTf were determined from a plot of $\ln \left(k_{\mathrm{rac}}\right) / \mathrm{T}$ versus $1 / \mathrm{T}$ where $k_{\text {rac }}=k_{\text {obs }} /[$ catalyst $]\left(y=-4206 x+9.62 ; R^{2}=0.95\right)$ (Figure 4). Pseudo first-order rate constants for the racemization of $(R)-3 \mathbf{b},(R)-3 \mathbf{c}$, and $(R)-3 \mathbf{d}$ catalyzed by (IPr)AuOTf were determined employing similar procedures (Figure S2, Table 1, entries 8-10). The enantiopurity of $(R)$-3b and $(R)$-3c were determined employing the conditions noted above; the enantiopurity of $(R)$ 3d was determined by HPLC analysis employing chiral stationary phase $\left[t_{r}\right.$ (major) $=17.3$ min, $t_{r}$ $($ minor $)=16.6 \mathrm{~min} ;$ solvent $=0.2 \%$ isopropanol-hexanes; flow rate $=0.5 \mathrm{~mL} / \mathrm{min}]$.

Figure S2. Pseudo first-order plots for the racemization of $(R)-3 \mathbf{a}(\square),(R)-3 \mathbf{b}(\triangle),(R)-3 \mathbf{c}(\backslash)$, and $(R)-3 \mathbf{d}(\mathrm{O})$, catalyzed by a 1:1 mixture of (IPr)AuCl and $\mathrm{AgOTf}$ in toluene at $25^{\circ} \mathrm{C}$.

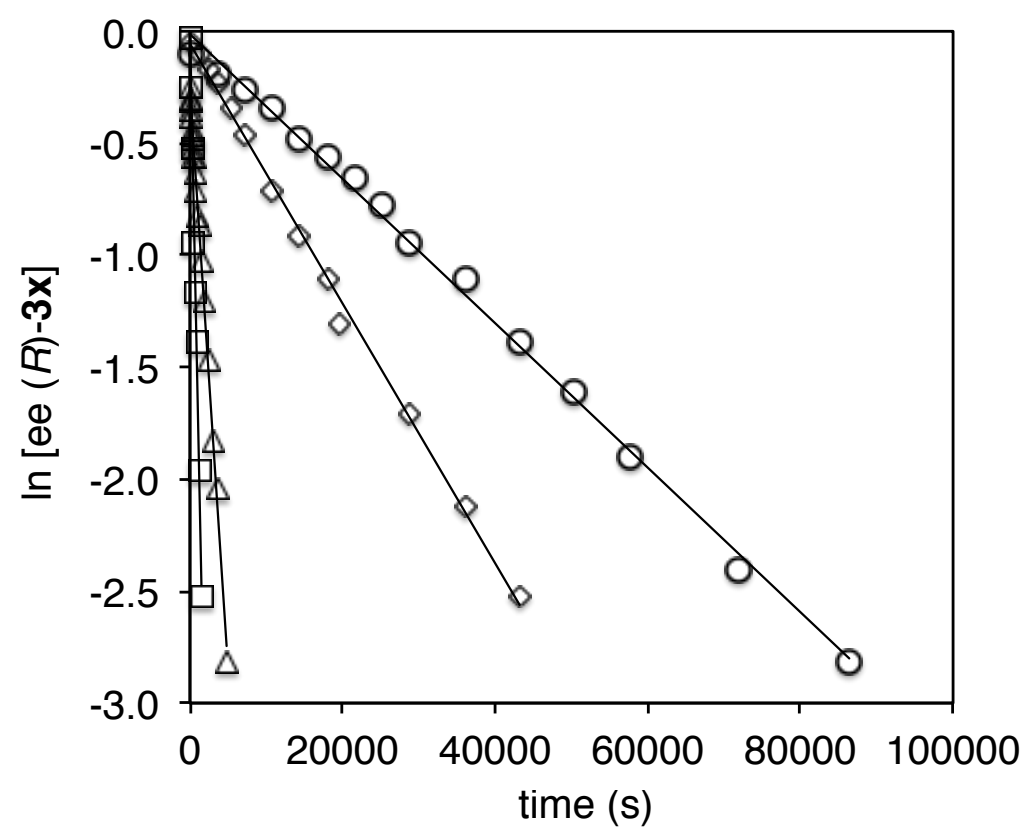


Figure S3. Pseudo first-order plots for the racemization of $(R)-3 a$ catalyzed by a 1:1 mixture of (IPr)AuCl and AgOTf in toluene at $9(\square), 40(O)$, and $55(\triangle){ }^{\circ} \mathrm{C}$.

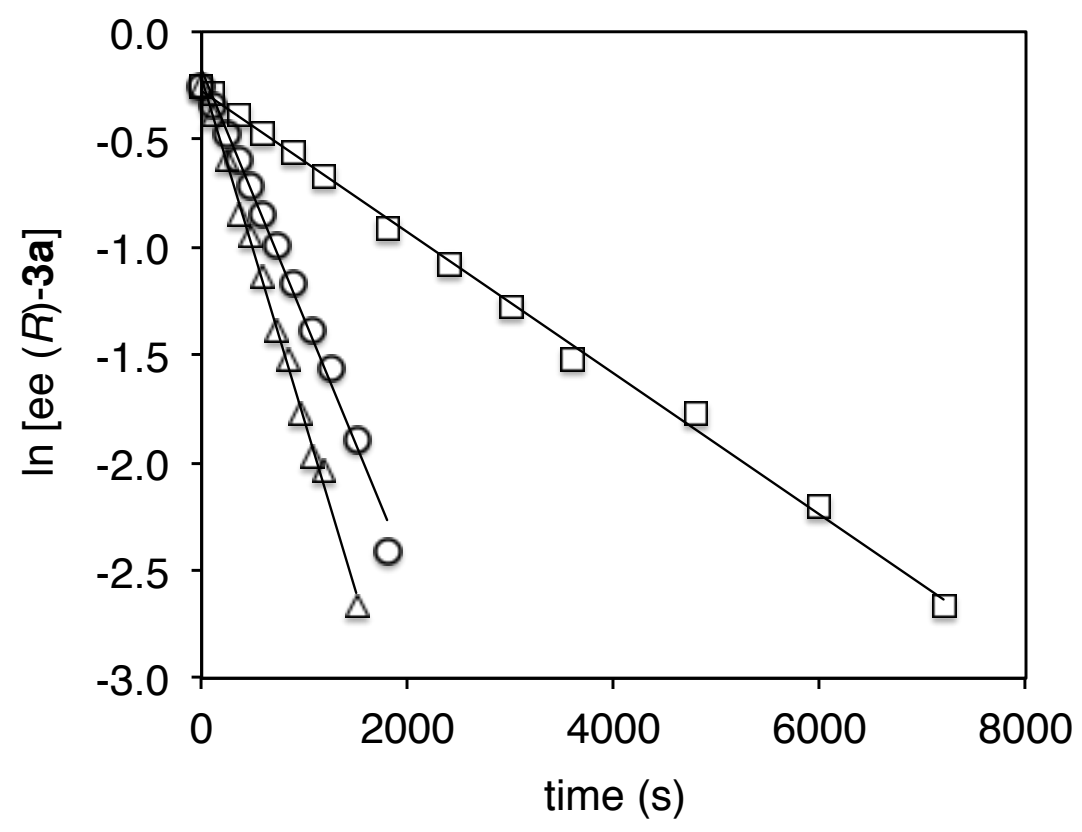

Kinetic Analysis of the Racemization of (S)-1 catalyzed by (P1)AuOTf. Pseudo-firstorder rate constants for the racemization of $(S)-1(100 \mathrm{mM})$ catalyzed by (P1)AuOTf $(\sim 10 \mathrm{mM})$ were determined employing procedures analogous to that used to determine $k_{\mathrm{obs}}$ for the racemization of (S)-1 catalyzed by (IPr)AuOTf (Figure S4). Activation parameters were determined employing a procedure analogous to that described for the racemization of $(R)-3$ a catalyzed by (IPr)AuOTf (Figure 5). 
Figure S4. Pseudo first-order plot for the racemization of $(S)-1(100 \mathrm{mM})$ catalyzed by a $1: 1 \mathrm{mixture}$ of (P1)AuCl and $\mathrm{AgOTf}(\sim 10 \mathrm{mM})$ in toluene at $25^{\circ} \mathrm{C}(\square), 35(\triangle)$, and $45^{\circ} \mathrm{C}(\mathrm{O})$.

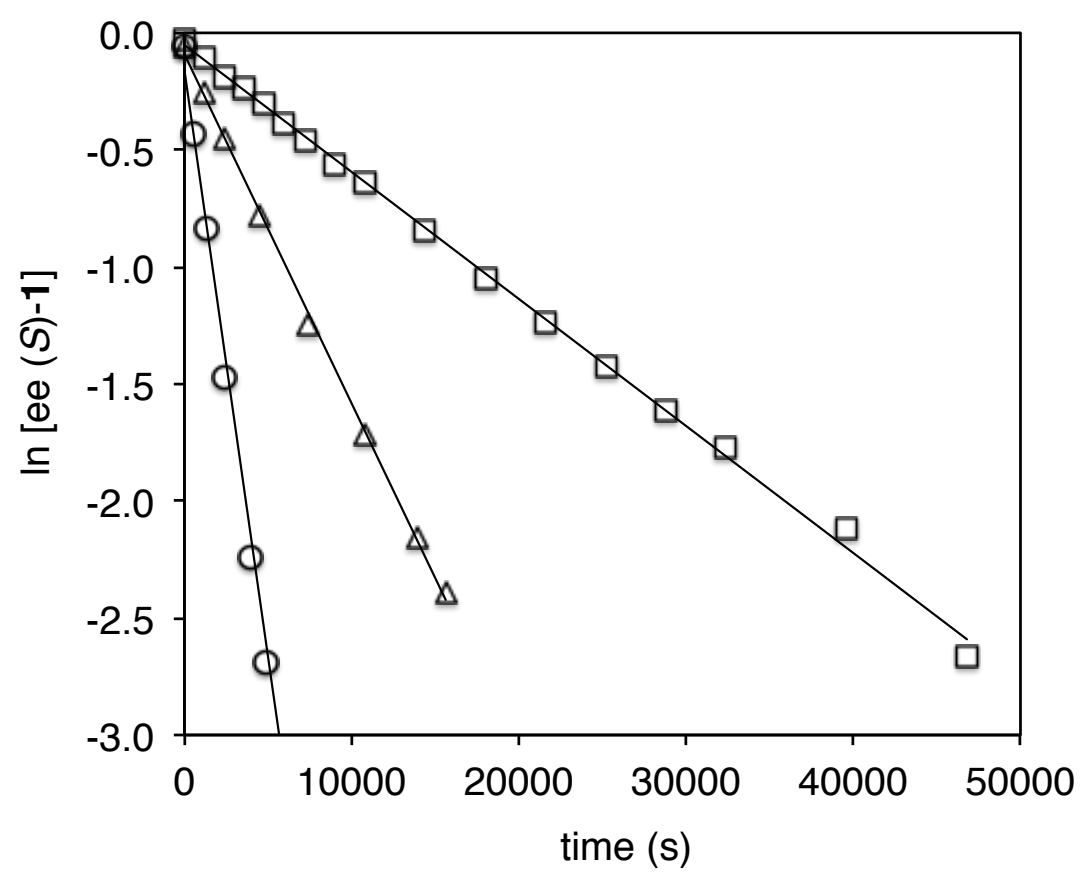

Kinetics of the conversion of $(S)-1$ to 2 . A solution of (IPr)AuOTf $\left(1.5 \times 10^{-2} \mathrm{mmol}\right)$ in toluene was prepared by dissolving (IPr)AuCl $\left(9.3 \mathrm{mg}, 1.5 \times 10^{-2} \mathrm{mmol}\right)$ and $\mathrm{AgOTf}(3.9 \mathrm{mg}, 1.5 \times$ $\left.10^{-2} \mathrm{mmol}\right)$ in toluene $(0.30 \mathrm{~mL})$ and stirring for $5 \mathrm{~min}$ at $25^{\circ} \mathrm{C}$. To this was added a solution of $(S)-1$ $(37.6 \mathrm{mg}, 0.20 \mathrm{mmol})$ in toluene $(0.20 \mathrm{~mL})$ and the resulting solution $\{[(S)-1]=0.40 \mathrm{M},[(\operatorname{IPr}) \operatorname{AuOTf}]=$ $50 \mathrm{mM}\}$ was stirred in a thermostatted oil bath at $25 \pm 0.5^{\circ} \mathrm{C}$. To monitor reaction progress, aliquots were removed periodically via syringe and analyzed by HPLC. A plot of In [ee (S)-1)] versus time was linear to $\sim 3$ half-lives, which established the first-order dependence on the rate of conversion of (S)-1 to 2 with a pseudo first-order rate constant of $k_{\mathrm{obs}}=1.26 \pm 0.03 \times 10^{-4} \mathrm{~s}^{-1}$ (Figure S5, Table S1, entry 3). Analogous experiments were performed with [(IPr)AuOTf = 30, 40, and $70 \mathrm{mM}$ (Table S1). A plot of $k_{\text {obs }}$ versus [(IPr)AuOTf was linear (Figure S6), which established the first-order dependence 
of the rate on [catalyst] and overall the second-order rate law for the conversion of $(S)-1$ to 2 : rate = $k_{2}[(S)-1][$ cat $]$, where $k_{2}=2.57 \pm 0.07 \mathrm{M}^{-1} \mathrm{~s}^{-1}\left(\Delta G^{\ddagger} 298 \mathrm{~K}=20.97 \pm 0.01 \mathrm{kcal} / \mathrm{mol}\right)$.

Table S1. Pseudo first-order rate constants for the conversion of (S)-1 to 2 catalyzed by a 1:1 mixture of (IPr)AuCl and AgOTf in toluene at $25^{\circ} \mathrm{C}$.

\begin{tabular}{ccc}
\hline entry & [cat] $(\mathrm{mM})$ & $\left(10^{5}\right) k_{\mathrm{obs}}\left(\mathrm{s}^{-1}\right)$ \\
\hline 1 & 30 & $8.36 \pm 0.05$ \\
2 & 40 & $11.5 \pm 0.2$ \\
3 & 50 & $12.6 \pm 0.3$ \\
4 & 70 & $17.6 \pm 0.5$ \\
\hline
\end{tabular}

Figure S5. Pseudo first-order plots for the conversion of (S)-1 to 2 catalyzed by a 1:1 mixture of (IPr)AuCl and AgOTf [30 mM (×),40 mM ( $\square), 50 x \mathrm{mM}(\triangle)$. and $70 \mathrm{mM}(\mathrm{O})]$ in toluene at $25^{\circ} \mathrm{C}$.

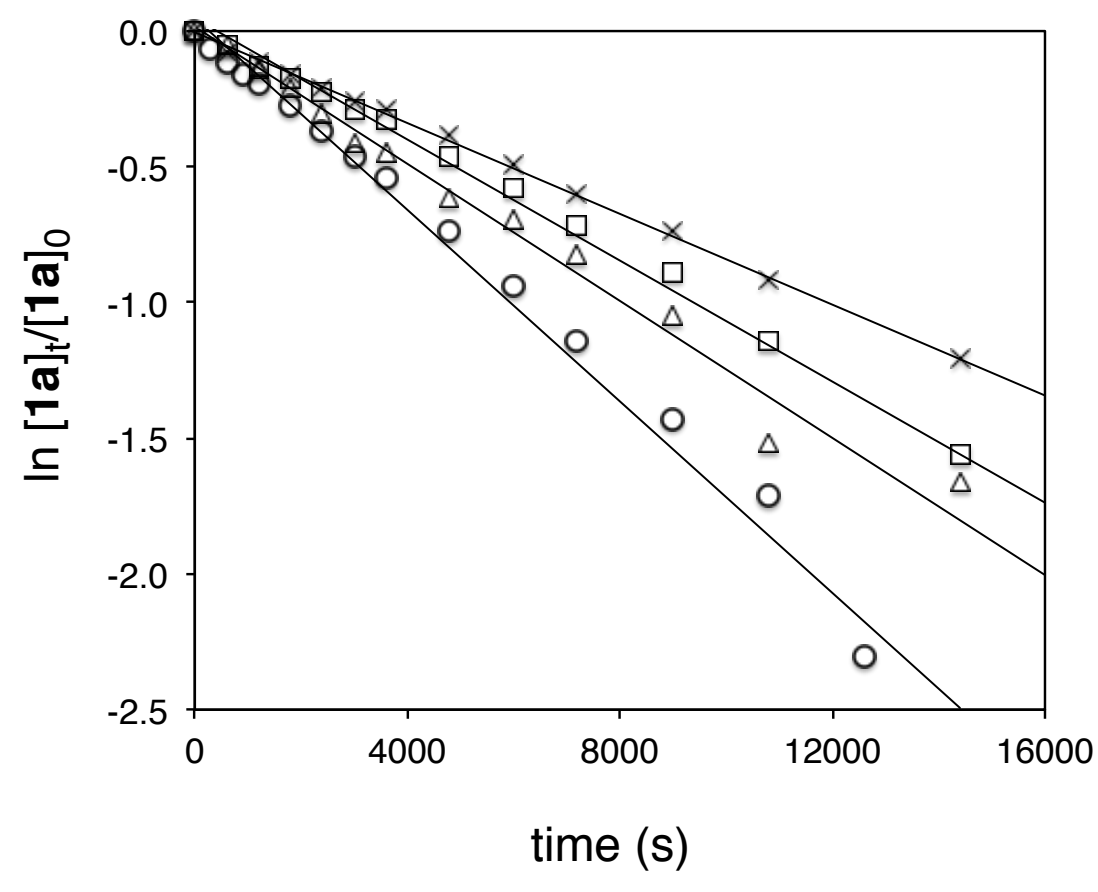


Figure S6. Plot of $k_{\text {obs }}$ versus catalyst concentration for conversion of (S)-1 to 2 catalyzed by a $1: 1$ mixture of (IPr)AuCl and $\mathrm{AgOTf}$ in toluene at $25^{\circ} \mathrm{C}$.

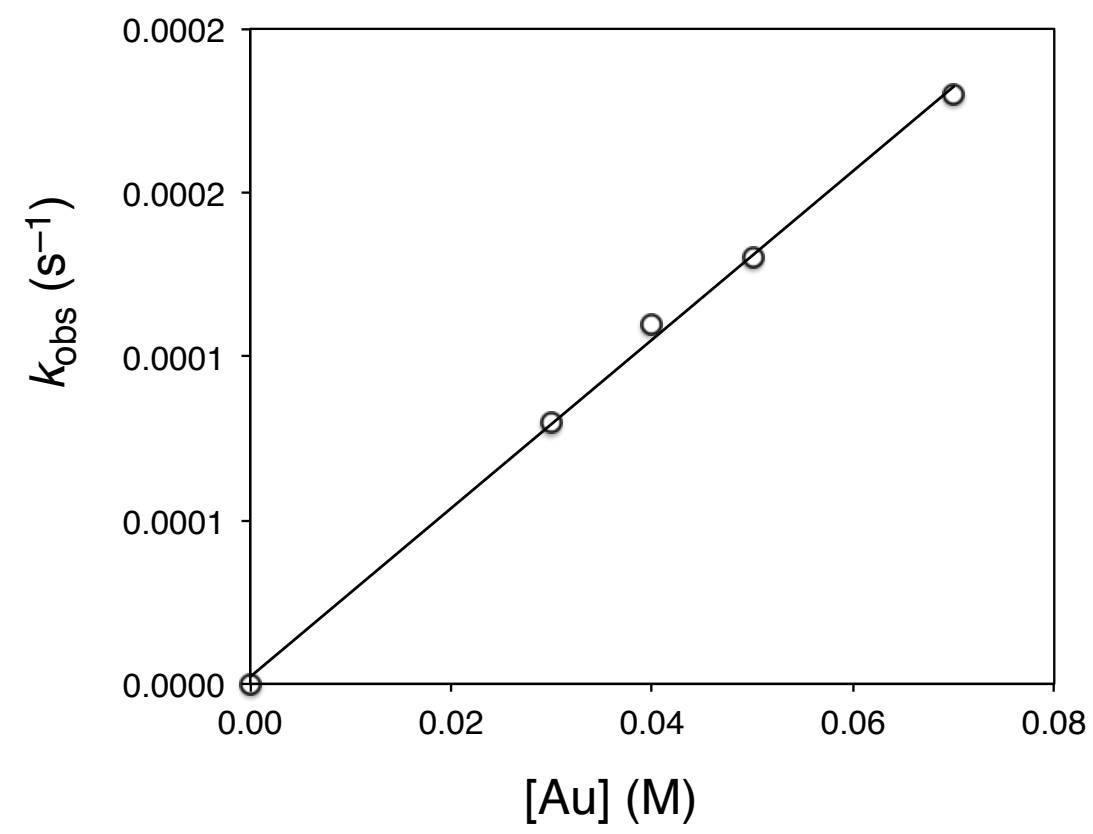

Penta-1,3-dien-2-yl benzoate (2). A solution of (S)-1 (37.6 mg. $0.020 \mathrm{mmol})$ in toluene (0.30 $\mathrm{mL}$ ) was added to a solution of (IPr)AuCl (12.6 mg, $0.020 \mathrm{mmol})$ and AgOTf (5.2 $\mathrm{mg}, 0.020 \mathrm{mmol})$ in toluene $(0.20 \mathrm{~mL})$ and the resulting solution was stirred at $25{ }^{\circ} \mathrm{C}$ for $24 \mathrm{~h}$. Aqueous work up followed by chromatography $\left(\mathrm{SiO}_{2}: \mathrm{CH}_{2} \mathrm{Cl}_{2}\right.$-hexanes $\left.=1: 2\right)$ of the residue gave $2(33 \mathrm{mg}, 88 \%)$ as a colorless oil comprised of a 1.2:1 mixture of isomers. ${ }^{1} \mathrm{H}$ NMR $\left(\mathrm{CDCl}_{3}, 1.2: 1\right.$ mixture of isomers): $\delta[8.21(\mathrm{~d}, \mathrm{~J}$ $=8.4 \mathrm{~Hz}), 8.16(J=8.4 \mathrm{~Hz}) 1: 1.2 \mathrm{H}],[7.62(\mathrm{q}, J=7.6 \mathrm{~Hz}), 7.50(\mathrm{q}, J=8.0 \mathrm{~Hz}), 1: 1.2 .3 \mathrm{H}),[6.66(\mathrm{dd}$, $J=10.8,16.8 \mathrm{~Hz}), 6.34(\mathrm{dd}, J=10.8,17.2 \mathrm{~Hz}), 1.2: 1,1 \mathrm{H}], \quad[5.54(\mathrm{q}, J=6.8 \mathrm{~Hz}), 5.47(\mathrm{q}, J=7.2$ $\mathrm{Hz}), 1: 1.2,1 \mathrm{H}],[5.27(\mathrm{~d}, J=16.8 \mathrm{~Hz}), 5.17(\mathrm{~d}, J=18.0 \mathrm{~Hz}), 1.2: 1,1 \mathrm{H}], \quad[5.16(\mathrm{~d}, J=10.4 \mathrm{~Hz}), 5.04$ $(\mathrm{d}, J=10.8 \mathrm{z}), 1.2: 1,1 \mathrm{H}], 1.87\left(\mathrm{~d}, J=7.2 \mathrm{~Hz},[1.67(\mathrm{~d}, J=6.8 \mathrm{~Hz}), 1.2: 1,3 \mathrm{H}] .{ }^{13} \mathrm{C}\left\{{ }^{1} \mathrm{H}\right\} \mathrm{NMR}\right.$ $\left(\mathrm{CDCl}_{3}, 1.2: 1\right.$ mixture of isomers): $\delta[165.1,163.8(1.2: 1)],[146.8,145.7(1: 1.2)],[133.4,133.3$ (1:1.2)], 131.3, [130.1, $130.0(1: 1.2)],[128.5,128.5(1: 1.2)], 126.2$, [117.6, 117.0 (1:1.2)], [114.3, $112.3(1.2: 1)]$, [11.7, $11.4(1.2: 1)]$. 
Figure S7. ${ }^{1} \mathrm{H}$ NMR spectra of $(R)-3 \mathbf{b}$.

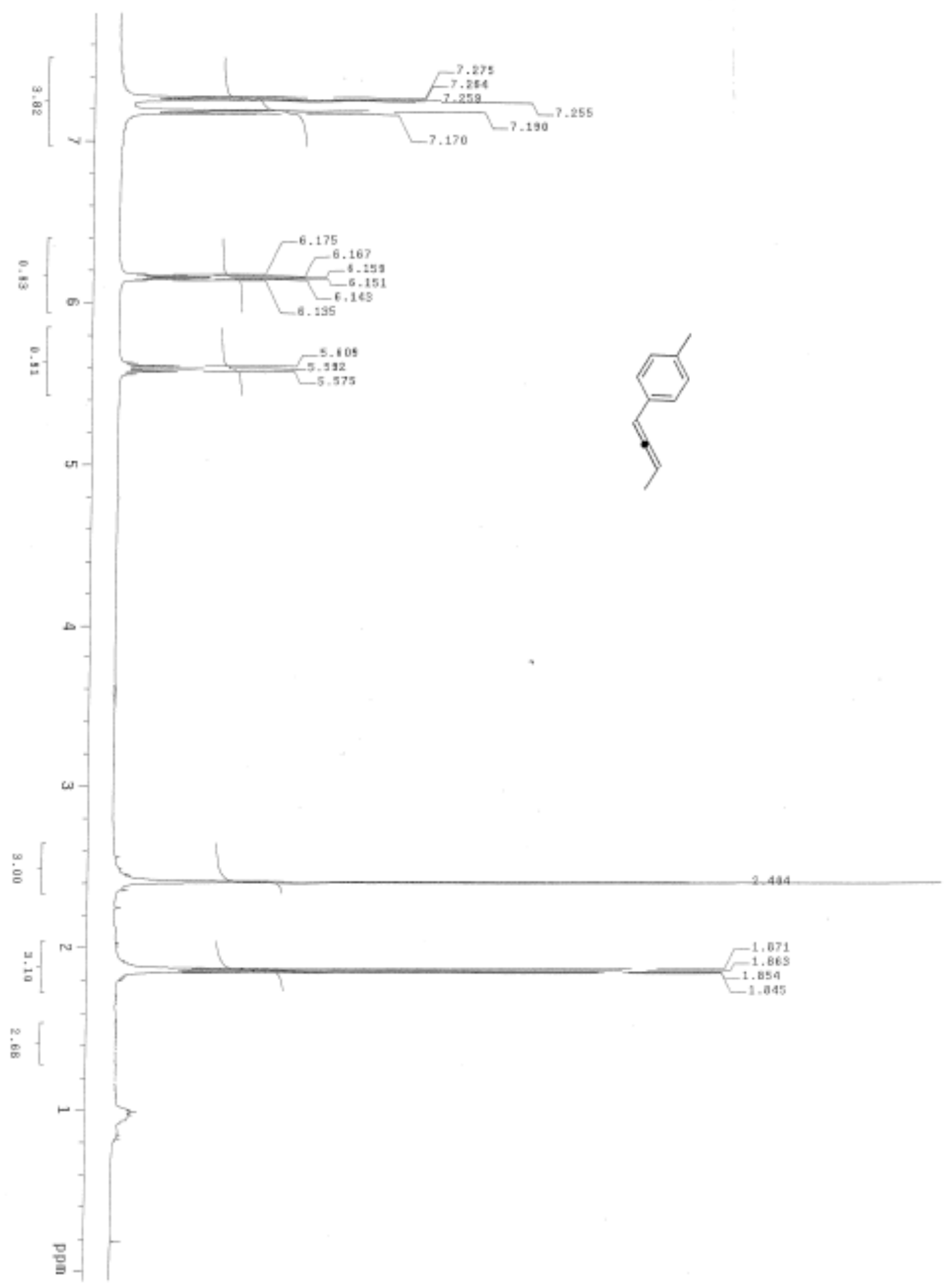


Figure S8. ${ }^{13} \mathrm{C}$ NMR spectra of $(R)-3 \mathbf{b}$.

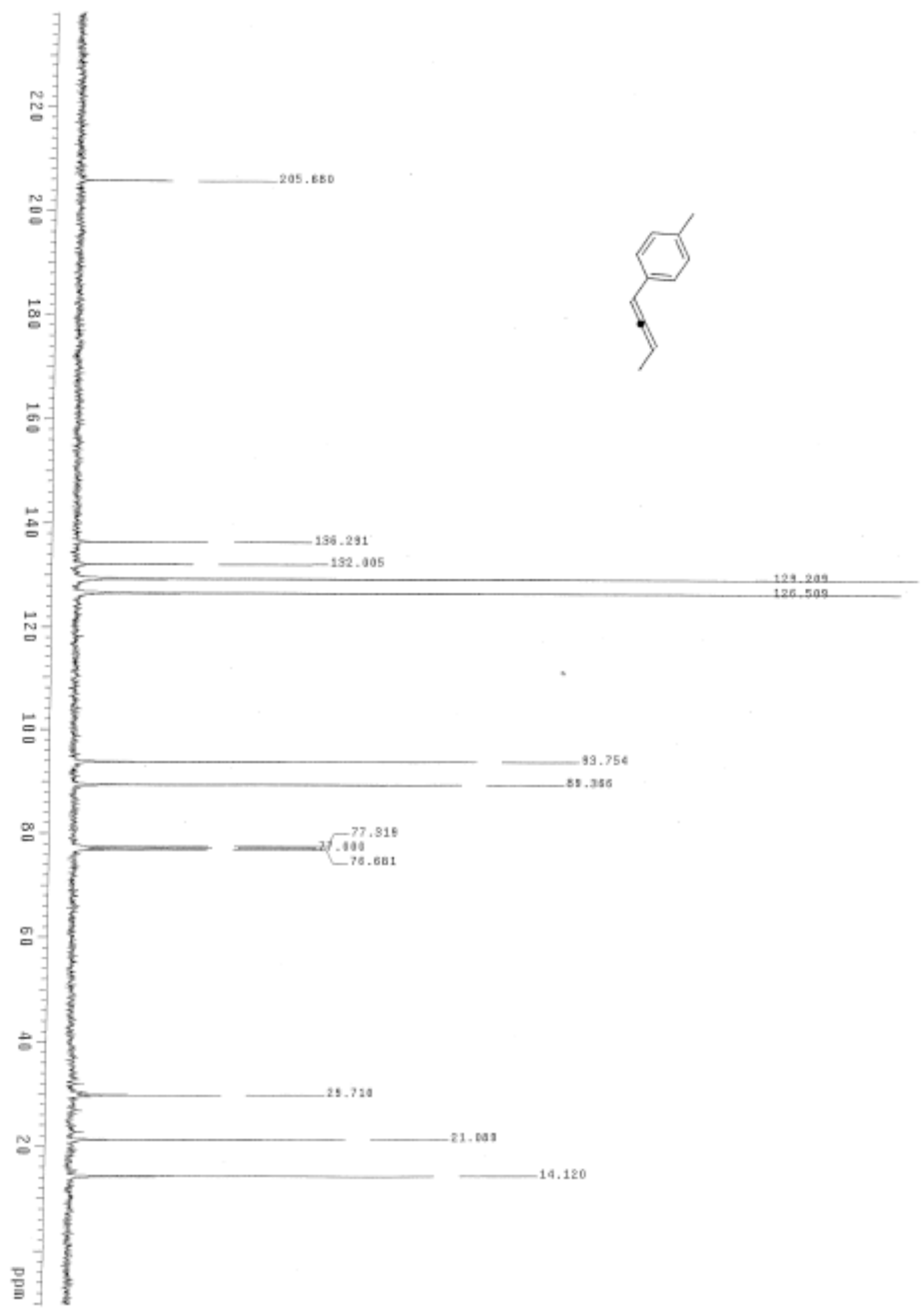


Figure S9. ${ }^{1} \mathrm{H}$ NMR spectra of $(R)-3 \mathrm{c}$.
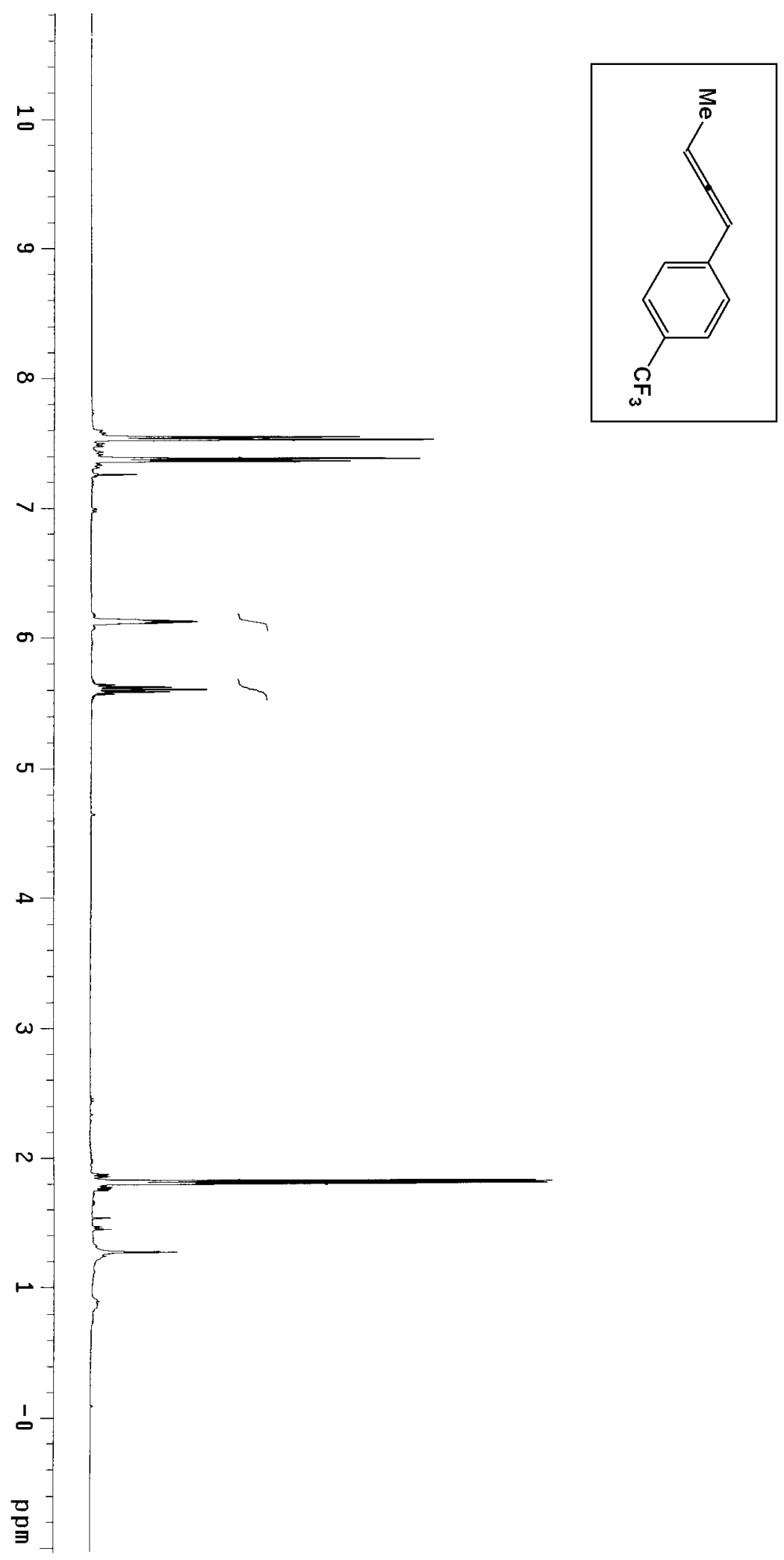
Figure S10. ${ }^{13} \mathrm{C}$ NMR spectra of $(R)-3 \mathrm{c}$.
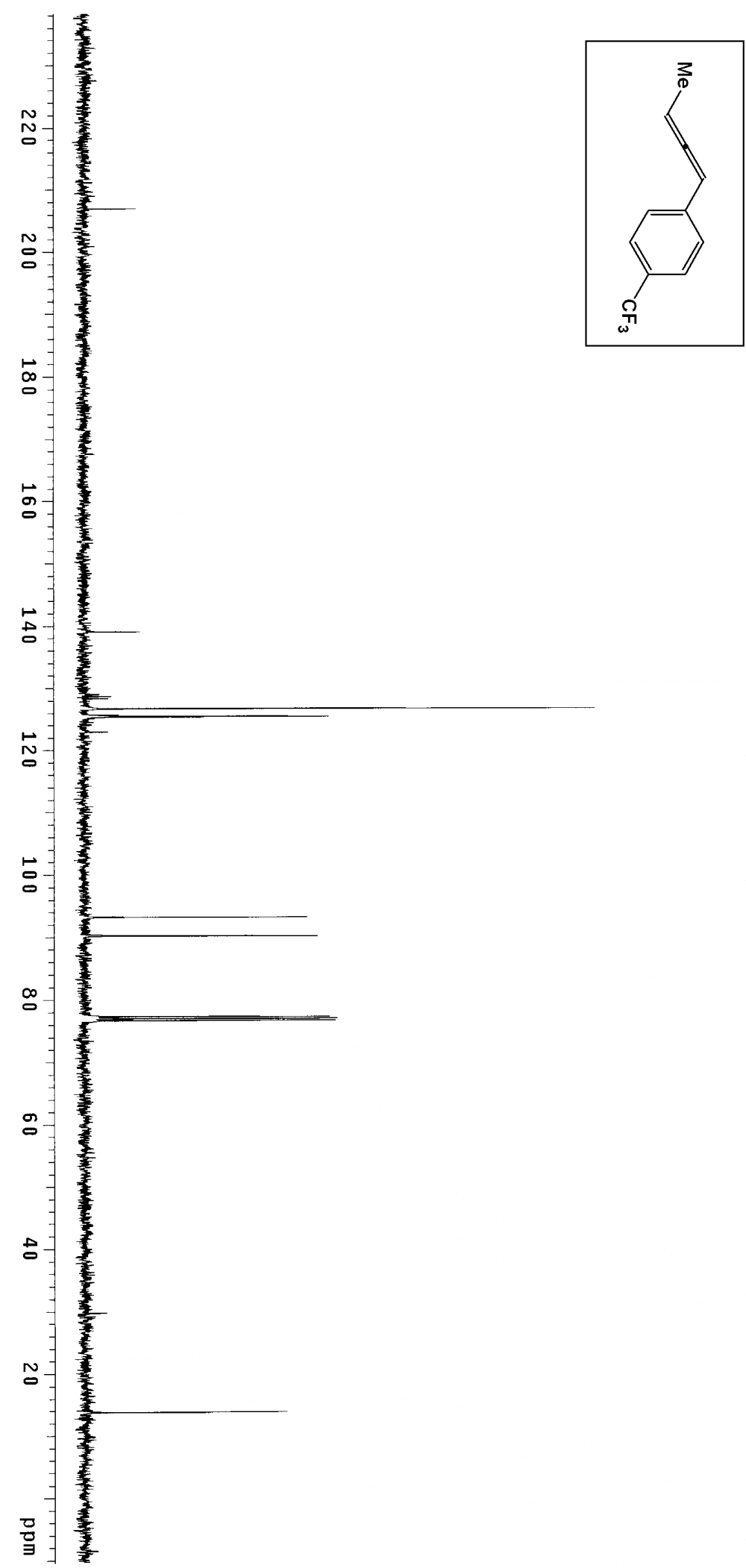


\section{References}

S1) Tao, B.; Ruble, J. C.; Hoic, D. A.; Fu, G. C. J. Am. Chem. Soc. 1999, 121, 5091.

S2) Nakamura, K.; Takenaka, K.; Ohno, A. Tetrahedron: Asymmetry 1998, 9, 4429.

S3) Zhang, Z.; Widenhoefer, R. A. Org. Lett. 2008, 10, 2079.

S4) Lee, K.; Seomoon, D.; Lee, P. Angew. Chem. Int. Ed. 2002, 41, 3901.

S5) A. G. Myers, B. Zheng, J. Am. Chem. Soc. 1996, 118, 4492-4493.

S6) Furukawa, J.; Kawabata, N.; Fujita, T. Tetrahedron 1970, 26, 243. 